\title{
Renaissance mercurial therapy in the mummies of Saint Domenico Maggiore in Naples: a palaeopathological and palaeotoxicological approach
}

\author{
Antonio Fornaciari ${ }^{1}\left[\right.$ S Silvio Chericoni ${ }^{2} \cdot$ Fabio Stefanelli ${ }^{2} \cdot$ Gino Fornaciari $^{1} \cdot$ Valentina Giuffra $^{1}$
}

Received: 20 April 2020 / Accepted: 19 January 2022 / Published online: 26 February 2022

(c) The Author(s) 2022

\begin{abstract}
This study was designed to evaluate the use of mercury therapy in the Italian noble classes of the Renaissance through the toxicological analysis of hair content. Mercury has stability and a long half-life in hair, representing a great resource not only for forensic toxicological analysis but also for archaeological research on mercurial exposure in past populations. The hair of fourteen mummified individuals of the Aragon and vice-royal court of Naples, buried in the Neapolitan Basilica of Saint Domenico Maggiore (15-18th centuries), was analysed by atomic absorption spectroscopy (AAS) and flame emission spectroscopy (FES). Out of the fourteen individuals, four presented mercury concentrations in the hair washing liquid indicating external perimortem application (in one case clearly linked to embalming, in three cases probably associated with topical therapeutic practices), three showed no traces of mercury, and seven had mercury values in hair ranging from 411 to $47 \mathrm{ppm}$, which indicate prolonged exposure in life to the metal. The historical identification of most of the mummified bodies with important nobles of Naples has allowed to compare the toxicological analyses with the nosography of the individuals and with the palaeopathological results deriving from the direct study of their bodies. Prolonged exposure in life to the metal was most likely due to mercurial anti-syphilitic therapy, as a consequence of its indiscriminate use in Renaissance therapies and, indirectly, as an effect of the extraordinary spread of venereal syphilis in the Italian upper classes during the "epidemic" phase of the disease.
\end{abstract}

Keywords Mercury $\cdot$ Mummies $\cdot$ Hair $\cdot$ Syphilis $\cdot$ Renaissance $\cdot$ Palaeotoxicology

\section{Introduction}

\section{Mercury exposure in palaeopathological literature}

The chemical analysis of bones can reveal the presence of $\mathrm{Hg}$ as trace element, and this evidence may disclose interesting palaeopathological insights into the use of mercurial therapy for different skin diseases such as leprosy and especially syphilis, once diagenesis has been excluded with the measurements of soil samples taken around the grave

Antonio Fornaciari

antonio.fornaciari@med.unipi.it

1 Division of Palaeopathology, Department of Translational Research and of New Technologies in Medicine and Surgery, University of Pisa, Via Roma 57, 56126 Pisa, Italy

2 Forensic Toxicology Laboratory, Department of Surgical, Medical, Molecular, Pathology and Critical Care, University of Pisa, Pisa, Italy
(Yamada et al. 1995; Tucker 2007; Rasmussen et al. 2008; Kepa et al. 2012).

In mummified bodies, hair is an important archaeological find to evaluate the exposure to heavy metals of past populations (Fresnais et al. 2015; Kakoulli et al. 2014; Bartkus et al. 2011; Byrne et al. 2010; Arriaza et al. 2010; Egeland et al. 2009; Wilson 2005; Egeland et al. 1999). Hair can be a marker of the chemical body burden of an individual by endogenous incorporation of trace metals; it is also used in clinical methodology to assess $\mathrm{Hg}$ exposure, because hair reflects the $\mathrm{Hg}$ blood level concomitantly to its formation (Nuttal 2006; Toribara 2001). The internationally recommended limit of hair mercury concentration is $1 \mathrm{ppm}$, as proposed by the WHO, and hair mercury concentration does not generally exceed $10 \mathrm{ppm}$ in a regular environment (Ye et al. 2016). Even if hair and blood specimens simultaneously collected may not be exactly correlated (McDowell et al. 2004), according to some authors (Nuttal 2006; Clarkson et al. 2003a, b), to the U.S. Food and Drug Administration 
(FDA) (US EPA 2001), and to the World Health Organization (WHO 1976), the hair-to-blood mercury concentration ratios are 250-300:1.

Similarly, the ratio set by a 2010 Korean study on a sample of 1200 residents was about 278.5:1 (Kim et al. 2013). Therefore, an estimation of blood $\mathrm{Hg}$ concentration can be made considering that $1 \mathrm{ppm}$ in hair may correlate to approximately $0.003-0.004 \mathrm{ppm}$ in blood.

Mercury has a long half-life in hair and stability over long periods of time, representing a great resource not only for forensic toxicological analyses but also for archaeological research on mercurial exposure in past populations (Egeland et al. 1999, 2009; Wilson 2005) and in historical figures (Chevallier et al. 2006; Reiter 1994). However, in the palaeopathological literature, evidence of exposure to mercury from the hair analysis of mummified bodies is rare.

The hair of the mummified body of Ferdinand II of Aragon (1467-1496), King of Naples, had already been analysed by atomic absorption spectroscopy (AAS) and flame emission spectroscopy (FES) in 2011, showing a high concentration of mercury resulting from the external application of the metal as anti-lice therapy (Fornaciari et al. 2011).

The analysis of the black patina on the teeth of Isabel of Aragon (1470-1524), Duchess of Milan, already performed in the 1980s of the past century by energy dispersive X-ray spectrometry (EDS), revealed chronic mercury intoxication probably related to an anti-syphilitic mercurial therapy (D'Errico et al. 1988).

In 2014, new analyses performed on the hair of Ferdinand II of Aragon and of Isabel of Aragon by synchrotron microbeam techniques confirmed previous results and the effectiveness of the AAS and FES methods (Lanzirotti et al. 2014), which have now been extended to other individuals of the Neapolitan series.

In this study, AAS and FES were used to analyse the hair samples of 14 individuals from the sacristy of Saint Domenico Maggiore in Naples (Fornaciari 2006) to obtain new data about the exposure to mercury in the Renaissance and in post-mediaeval times.

The aim of this study is to evaluate the presence of mercury for therapy and cosmetics in the Italian noble classes of the Renaissance. Mercury was already employed in mediaeval pharmacopoeia in a heterogeneous class of very different skin diseases (Tognotti 2006). For this reason, although dangerous, it started to be used at the end of the 15th century for the treatment of syphilis, considered a skin disease similar to leprosy: the therapy was so aggressive that the cure for the patients was often more lethal than the disease itself (Tilles and Wallach 1996). In the 16th century, Paracelsus (1493-1541) strongly promoted the medical use of metals, also as internal remedies, in particular of mercury, antimony, and arsenic, which represented a very important therapeutic tripod of Iatrochemistry. For Paracelsus and for
Paracelsian physicians, mercury was the principal element of anti-syphilitic chemotherapy (Debus 2002).

As reported in 16th century texts, mercury was also frequently employed in cosmetic recipes: sublimates of mercury and quicksilver were included in the composition of products designed to whiten the skin, or to remove erythema, blotches, and freckles from the face, or to treat putrid ulcers and sores, pocks, and warts (Drew-Bear 1994; Fornaciari et al. 2011). In the Renaissance, mercury was also used as antiputrefactive in the embalming process. Although not clearly attested in the historical sources, palaeopathological findings evidenced the use of mercurial compounds for funerary embalming treatments in the late Medieval and Modern Ages (Charlier et al. 2013, 2014; Marinozzi 2013; Marinozzi and Fornaciari 2005; Le Roy 1919).

The historical identification of most of the mummified bodies of Saint Domenico Maggiore allowed to compare the nosography and lifestyle of the individuals with palaeopathological results deriving from direct study of the bodies and toxicological analysis of the hair.

\section{Materials and methods}

\section{Materials}

The Basilica of San Domenico Maggiore, which dates back to the beginning of the 14th century, is one of the largest and most important churches in Naples. The impressive Sacristy of San Domenico Maggiore, in a suspended gateway close to the vault, contains 38 wooden sarcophagi with the bodies of 10 Aragonese princes and other Neapolitan nobles, who died between the 15th and 18th centuries, but mainly during the 16th century (Fig. 1). The series includes many artificial as well as natural mummies and skeletonized remains (Fornaciari 1998, 2006). Thirteen individuals showed well-preserved hair; the hair samples were obtained during autopsy of the bodies performed in the years 1984-1987. Another specimen was that of a female bride found in the coffin of Ferdinand Francis of Avalos, Marquise of Pescara (1490-1525). Conservation inside coffins, which prevented the body's contact with soil - as usually happens in archaeological burials excludes forms of diagenetic contamination of the bodies.

The autopsies of all the mummies were conducted by palaeopathologists wearing sterile surgical coats, sterile latex gloves, sterile masks, headdresses, and overshoes. The samples used for analysis were collected at the start of the autopsies, and immediately stored in sealed, sterile plastic bags. The following is a detailed list, in chronological order from the oldest to the most recent, of the samples identified by the acronym NASD (NAples. Saint Domenico) and a number (Table 1). 


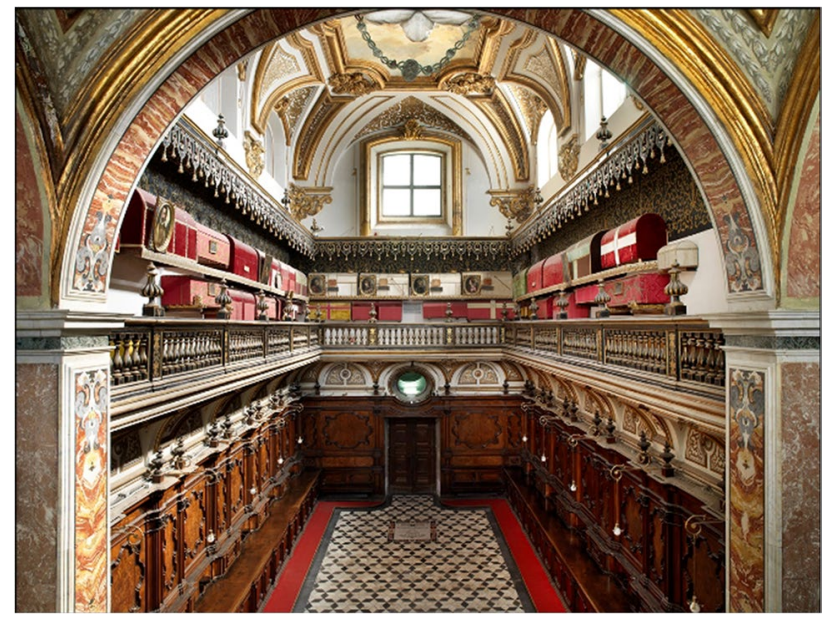

Fig. 1 The monumental Sacristy of San Domenico Maggiore in Naples. On the suspended gateway are the wooden sarcophagi of the royal dynasty of Aragon and other Neapolitan nobles (Campania CRBC)

The attribution of the individuals to single historical figures was possible on the basis of the archaeological context (epigraph, dress style, radiocarbon dating of the coffin), anthropological data (sex, age at death), and historical documents. What appears below is a brief description of the single individuals with essential data, information about state of preservation, identification, treatment of the body, anamnestic, and palaeopathological data.

\section{NASD 20 Ferdinand II of Aragon, King of Naples (1467- 1496)}

The mummy is badly preserved; however, strands of dark hair are still present. He was identified thanks to the epigraph and to dress style (D'Arbitrio 2001). Ferdinand II was embalmed and submitted to craniotomy and to evisceration by a xipho-pubic cut. The body was filled with sponges soaked in resinous substances and clay.

Examination of the head hair and of the pubic hairs by stereomicroscope and scanning electron microscopy (SEM) revealed the presence of remains of lice, demonstrating that the king was affected by pediculosis, namely by Pediculus capitis and by Pthirus pubis (Fornaciari et al. 2009, 2011).

\section{NASD 19 Joan IV of Aragon, Queen of Naples (1479-1518)}

The body is completely skeletonized with no traces of embalming but with preservation of some dark locks of hair.

Table 1 Acronym, sex, age, name and title, chronology, preservation treatment of the body, and pathology of the individuals with hair sampled from the Basilica of Saint Domenico Maggiore in Naples

\begin{tabular}{|c|c|c|c|c|c|}
\hline NASD & Sex & Age & Name and title/chronology & Preservation & Pathology \\
\hline 20 & M & 29 & $\begin{array}{l}\text { Ferdinand II of Aragon, King of Naples } \\
(1467-1496)\end{array}$ & Artificial mummy & Pediculosis \\
\hline 19 & $\mathrm{~F}$ & 39 & $\begin{array}{l}\text { Joan IV of Aragon, Queen of Naples (1479- } \\
\text { 1518) }\end{array}$ & Skeleton & $\begin{array}{l}\text { Severe periodontal disease. Severe thoraco- } \\
\text { lumbar scoliosis }\end{array}$ \\
\hline 17 & $\mathrm{~F}$ & 54 & $\begin{array}{l}\text { Isabel of Aragon, Duchess of Milan (1470- } \\
\text { 1524) }\end{array}$ & Skeleton & Mercury stomatitis \\
\hline $11 \mathrm{a}$ & M & 35 & $\begin{array}{l}\text { Ferdinand Francis of Avalos, Marquis of Pes- } \\
\text { cara }(1490-1525)\end{array}$ & Artificial mummy & Thoracic abscess by harquebus wound \\
\hline $11 b$ & $\mathrm{~F}$ & 55 & $\begin{array}{l}\text { Victoria Colonna (1492-1547), Marquise of } \\
\text { Pescara }\end{array}$ & Lock of hair & - \\
\hline 14 & M & $35-40$ ca. & $\begin{array}{l}\text { Ferdinand Orsini, Duke of Gravina (1485- } \\
\text { 1549) }\end{array}$ & Natural mummy & Basal cell carcinoma of the orbital skin \\
\hline 16 & $\mathrm{~F}$ & 65 & $\begin{array}{l}\text { Mary of Aragon, Marquise of Vasto (1503- } \\
1568)\end{array}$ & Artificial mummy & Tertiary syphilis \\
\hline 5 & $\mathrm{~F}$ & $10 \mathrm{ca}$. & $\begin{array}{l}\text { Unknown young girl (second half of 16th } \\
\text { century) }\end{array}$ & Skeleton & - \\
\hline 8 & M & $35-45$ ca. & $\begin{array}{l}\text { Unknown noblemen (second half of 16th } \\
\text { century) }\end{array}$ & Artificial mummy & Frontal sinusitis. Dorsal scoliosis \\
\hline 24 & M & $2-3$ ca. & Unknown baby (second half of 16th century) & Artificial mummy & Severe hepatitis B virus (HBV) infection \\
\hline 28 & M & $35-45 \mathrm{ca}$. & $\begin{array}{l}\text { Unknown noblemen (second half of 16th } \\
\text { century) }\end{array}$ & Artificial mummy & $\begin{array}{l}\text { Healed fracture on the left wrist. Healed trauma } \\
\text { on the right tibia }\end{array}$ \\
\hline 31 & $\mathrm{~F}$ & 49 & $\begin{array}{l}\text { Catherine of Moncada, Duchess of Montalto } \\
(1611-1659)\end{array}$ & Skeleton & $\begin{array}{l}\text { Periodontal disease. Severe dental caries. Mam- } \\
\text { mary carcinoma }\end{array}$ \\
\hline 26 & $\mathrm{~F}$ & $30-40 \mathrm{ca}$. & Unknown noblewoman (17th century) & Skeleton & Periodontal disease. Severe dental caries \\
\hline 33 & M & $50-60$ ca. & Charles Tocco, Duke of Sicignano $(† 1710)$ & Artificial mummy & Severe osteoarthritis of the spine and of the joints \\
\hline
\end{tabular}


She was identified thanks to the epigraph and dress style (D'Arbitrio 2001). From an "anamnestic" point of view, Joan was a sexually very active woman. After the death of her consort, she had numerous lovers, including Giovanni Castriota Scanderbeg and others mentioned in historical sources (Archi 1968; Scandone 1930).

\section{NASD 17 Isabel of Aragon, Duchess of Milan (1470-1524)}

The body - skeletonized, with no traces of embalming but with preservation of the hair - was identified thanks to the presence of the epigraph and dress style (D'Arbitrio 2001). Widow from 1494 of John Galeazzo Sforza, Duke of Milan, in 1500, she returned to the kingdom of Naples and dedicated herself to the government of the duchy of Bari. From an "anamnestic" point of view, Isabel led a very active sexual life even during widowhood. The famous warlord Prospero Colonna and her minister Giosuè di Ruggero are mentioned among her lovers (Archi 1968; Pepe 1900). The palaeopathological study of the skeletal remains shows that she suffered from a severe form of mercurial stomatitis in her last years of life. This condition resulted in a strong artificial wear of the anterior teeth, since Isabel tried to remove the black patina caused by the deposition of mercury salts excreted by the salivary glands (Fig. 2).

\section{NASD 11a Ferdinand Francis of Avalos (1490-1525)}

Ferdinand Francis of Avalos was Marquis of Pescara and Captain General of the army of Emperor Charles V. He defeated François I, King of France, in the battle of Pavia (1525), but he died the same year in which he was wounded in combat (Taylor 1973). He was identified by historical documents that reported his burial in the sacristy of Saint Domenico, by anthropological data (sex and age at

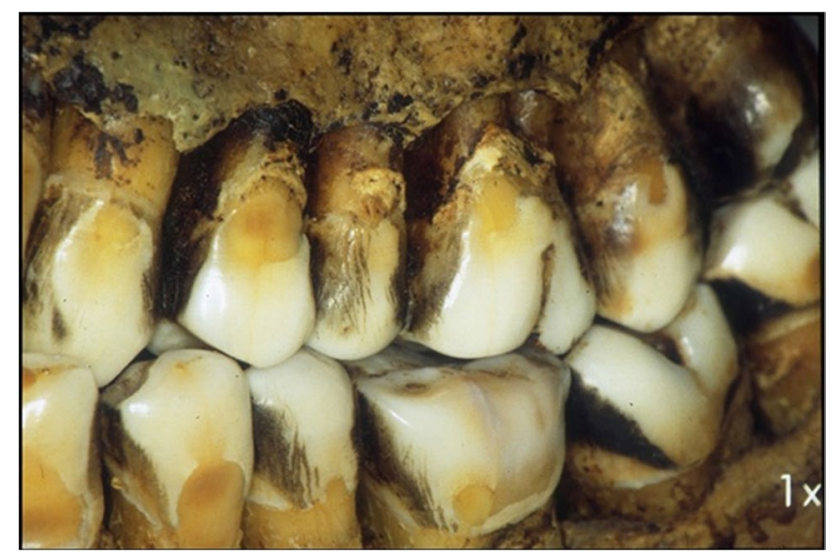

Fig. 2 Dentition of Isabel of Aragon (NASD 17): Detail of the left teeth with the macroscopic wear and the black patina caused by the deposition of mercury salts death), by the presence of a thoracic infected wound, and by his dress style (D'Arbitrio 2001).

His body is an artificial mummy with craniotomy (Fig. 3) and evisceration by jugular-pubic cut. The body was filled with wool, wadding, lime, and ash.

\section{NASD 11b Victoria Colonna (1492-1547) Marquise of Pescara, wife of Ferdinand Francis of Avalos?}

In 1525, a noblewoman cut a long lock of hair and deposed it on the coffin of Ferdinand Francis of Avalos as a sort of extreme gift. The lock of hair is reddish, about $25 \mathrm{~cm}$ long, and with a black ribbon as a sign of mourning. Historical sources do not mention this act, but the lock probably belonged to the Marquise Vittoria Colonna, wife of the Ferdinand Francis of Avalos. She was an important poetess, friend of Michelangelo Buonarroti, and founder of the literary circle of Ischia (Patrizi 1982). After her husband's death, Victoria led a very pious life and maintained perpetual mourning in memory of her beloved husband to whom her poetic production is almost entirely dedicated (Toscano 1998).

\section{NASD 14 Ferdinand Orsini, Duke of Gravina (1485-1549)}

Ferdinand's body, identified by the epigraph with his name and the date of death (1549), is preserved as natural mummy with no traces of embalming.

He died of a devastating basal cell carcinoma of the right orbit and of the root of the nose (Fornaciari et al. 1989c; Gaeta et al. 2017; Fornaciari 2018).

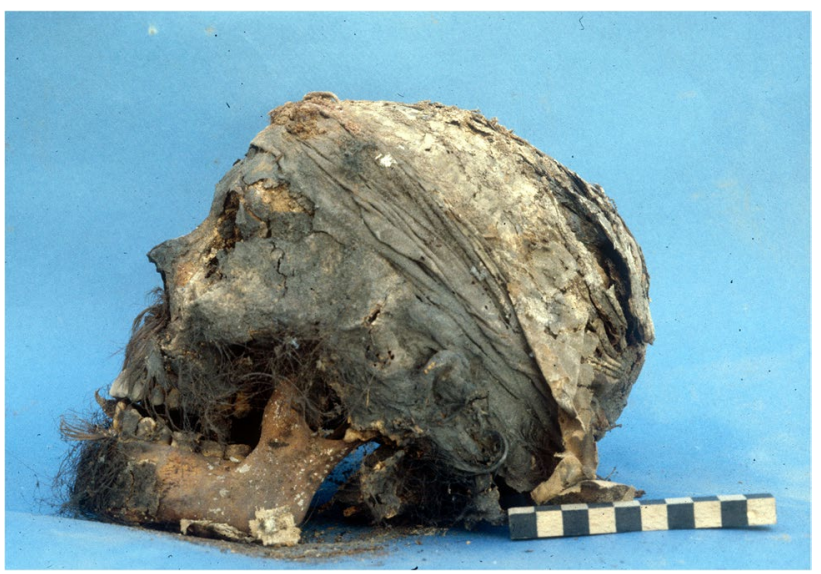

Fig. 3 The mummified head of Ferdinand Francis of Avalos (NASD11a) 
NASD 16 Mary of Aragon, Marquise of Vasto (1503-1568)

Mary of Aragon was identified thanks to the epigraph and dress style (D'Arbitrio 2001). Her body is an artificial mummy with evisceration by xipho-pubic and umbilicaltransverse cuts. The body was filled with lime overlapped with artemisia bouquets, laurel leaves, and myrtle sprigs. Mary of Aragon, granddaughter of the King of Naples Ferdinand I (1431-1494), married the Marquis Alphonso of Avalos (1502-1546), captain of the Emperor Charles V. In the last years of her life, she regularly attended the thermal baths of Asciano near Naples, renowned for the sulphurous springs, able to cure skin diseases (Fiorentino 1911).

From a palaeopathological point of view, the mummy presented a cutaneous ulcer on the left arm, bandaged and medicated with ivy leaves and a tampon made of sulphurimpregnated hemp (Giuffra et al. 2008). The histological, immunohistochemical, and ultrastructural study of the lesion revealed treponemes, identified as Treponema pallidum with the diagnosis of tertiary venereal syphilis (Fornaciari et al. 1989d).

\section{NASD 5 unknown female child of about 10 years (second half of 16 th century)}

We have no biographical information about this 10-year-old girl, wearing gold jewels and dressed in a sumptuous dress of the second half of the 16th century (D'Arbitrio 2001).

Her body is almost completely skeletonized with no traces of embalming but with preservation of some short blonde locks of hair.

\section{NASD 8 unknown male of 35-45 years (second half of 16th century)}

This is an artificial mummy with craniotomy, defleshing, and evisceration by xipho-pubic and umbilical-transverse cuts. The cranial cavity was filled with resinous dark-coloured material mixed with animal hair and droplets of mercury. The chest and abdominal cavities were filled with a kind of "felt," mixed with resins and mercury. Solid droplets of mercury were noticed at the time of undressing and of autopsy, and as radiopaque materials on the hair and inside the cavities of the skull and of the body at X-ray examination. The posterior cavities were covered with a layer of dust. The mummy dates back to the second half of the 16th century on account of the style of dress (D'Arbitrio 2001).

\section{NASD 24 unknown male child of 2-3 years (second half of 16 th century)}

This is an artificial mummy of a child, impossible to identify, with craniotomy and evisceration by jugular-pubic cut.
The body was filled with animal hair wadding mixed with resins. Radiocarbon $\left({ }^{14} \mathrm{C}\right)$ dating of the coffin is $1569 \mathrm{CE} \pm$ 60 years. The clothes style corresponds to the chronology of the second half of the 16th century. Palaeopathology of the mummy revealed an infection by hepatitis B virus (HBV), with vesiculopustular exanthema, and also the presence, at transmission electron microscopy (TEM), of large virus-like particles identified with smallpox in previous studies (Fornaciari and Marchetti 1986; Patterson Ross et al. 2018).

\section{NASD 28 unknown male of 35-45 years (second half of 16th century)}

It was not possible to identify this artificial mummy with craniotomy and evisceration by jugular-pubic and umbilicaltransverse cuts belonging to a male aged $35-45$ years. The body was filled with a sort of "felt" and with resinous substances. The mummy dates back to the second half of the 16th century thanks to the style of dress (D'Arbitrio 2001).

\section{NASD 31 Catherine of Moncada, Duchess of Montalto (1611-1659)}

The body was completely skeletonized with no traces of embalming but with preservation of her dark hair. She was identified thanks to the epigraph and by the 17th century dress style (D'Arbitrio 2001). From the historical sources, we know that she died of mammary cancer (Pilo 2018) and that her husband, Louis William of Moncada-Aragon, had suffered from venereal disease, probably syphilis, at least since 1649 (Pilo 2010).

\section{NASD 26 unknown adult female of 30-40 years (17th century)}

The body of a female aged 30-40 years, impossible to identify, was completely skeletonized with no traces of embalming but with preservation of a braid of dark hair tied with silk ribbons. Radiocarbon $\left({ }^{14} \mathrm{C}\right)$ dating of the coffin was $1639 \mathrm{CE}$ \pm 60 years (Fornaciari et al. 1989a).

\section{NASD 33 Charles Tocco, Duke of Sicignano (†1710)}

He was identified thanks to the presence of the ducal coat-ofarms of Sicignano on the coffin and thanks to the historical sources regarding his burial in Saint Domenico (Volpicella 1847). The dress style is compatible with the second half of the 17th century. Member of an important noble Neapolitan family (Shamà 2013), his body is an artificial mummy with craniotomy, defleshing, and evisceration by jugular-pubic cut. The body was filled with felt and raw fibres, probably wool. The back cavities appeared coated with a layer of claylike material of a dark reddish colour. 


\section{Analytical methods}

The hair samples of these personages, taken from the posterior region of the head, were washed twice with $2 \mathrm{ml}$ of a surface-active agent (Tween $800.1 \%$ ). Each sample of hair was placed on a vortex, shaken, and then mixed with $2 \mathrm{ml}$ of distilled water. The washing liquid was preserved and analysed by AAS. After washing, the hair was dried, cut into small bits, and subjected to acid digestion. This procedure was aimed at complete digestion of the hair matrix, before starting analysis in AAS. To this purpose, $100 \mathrm{mg}$ of hair were digested with $2 \mathrm{ml}$ of sulphuric acid mixture, perchloric acid, and nitric acid in the ratio of 125:25:1, respectively. The mixture was placed in the test tube and kept at $200{ }^{\circ} \mathrm{C}$ for $20 \mathrm{~min}$. All the samples and standards used for instrument calibrations were diluted with distilled water containing nitric acid $0.8 \mathrm{~N}$ at $0.5 \%$ and potassium bichromate at $0.1 \%$. This solution stopped mercury volatilization and loss.

Two different methods were used: AAS with graphite furnace (model 306 Perkin-Elmer) and flame emission spectrometry using the hydride method. The former method was used for preliminary screening in order to test the presence of mercury in the hair, using a cut-off value of $1 \mathrm{ppm}$. At a later stage, positive samples were analysed by flame emission spectrometry using the hydride method to determine the exact concentration of mercury. The sensitivity is $0.5 \mathrm{ppb}$ and, as regards specificity, the possibility of interference due to the extraction method was evaluated by analysing five samples which all gave a negative result.

In this case, the instrument employed was an ICP-AES (inductively coupled plasma-atomic emission spectrometry) Liberty 200 of Varian, connected to a VGA (Vapour Generation Accessory) 76P. The limit of quantification (LOQ) of the method was $0.5 \mathrm{ppb}$. The ICP-AES method was employed for quantitative analysis using a five-point calibration curve at the following concentrations: 0-0.5-210 and $20 \mathrm{ppm}$.

\section{Results}

The presence of mercury in the hair washing liquid made is the clear demonstration of an external application. Mercury was present and abundant in the hair washing liquid of one individual (NASD 8 ) and in traces of the washing liquid of three other individuals (NASD 20; NASD 28; NASD 33) (Tables 2,3). When mercury is absent in the hair washing liquid, the value in the hair certainly reflects the real "in
Table 2 Presence of $\mathrm{Hg}$ in the hair washing liquids and in the hair samples subjected to acid digestion by AAS
Table $3 \mathrm{Hg}$ concentration in hair samples with positive washing liquid by flame emission spectrometry

\begin{tabular}{llll}
\hline NASD & Name and chronology & $\begin{array}{l}\text { Hair washing } \\
\text { liquid }\end{array}$ & $\begin{array}{l}\text { Hair acid } \\
\text { digestion }\end{array}$ \\
\hline 20 & Ferdinand II of Aragon (1467-1496) & + & +++ \\
19 & Joan IV of Aragon (1479-1518) & - & ++ \\
17 & Isabel of Aragon (1470-1524) & - & +++ \\
$11-\mathrm{a}$ & Ferdinand Francis of Avalos (1490-1525) & - & ++ \\
$11-\mathrm{b}$ & Victoria Colonna (1492-1547)? & - & + \\
14 & Ferdinand Orsini (1485-1549) & - & ++ \\
16 & Mary of Aragon (1503-1568) & - & + \\
5 & Unknown young girl (second half 16th century) & - & +++ \\
8 & Unknown nobleman (second half 16th century) & +++ & - \\
24 & Unknown baby (second half 16th century) & - & + \\
28 & Unknown nobleman (second half 16th century) & + & ++ \\
31 & Catherine of Moncada (1611-1659) & - & - \\
26 & Unknown noblewoman (17th century) & - & ++ \\
33 & Charles Tocco (†1710) & + & + \\
\hline
\end{tabular}

$-=$ negative $(<1 \mathrm{ppm}) ;+=$ weakly positive (from 1 to $100 \mathrm{ppm}) ;++=$ positive (from 100 to $300 \mathrm{ppm}$ ); $+++=$ strongly positive (over $300 \mathrm{ppm})$

\begin{tabular}{lllrl}
\hline NASD & Name and chronology & Hair Hg (ppm) & Dev. St. & C. V. \% \\
\hline 20 & Ferdinand II of Aragon (1467-1496) & 827 & 5.52 & 0.53 \\
8 & Unknown nobleman (second half 16th century) & 3232 & 63.01 & 7.8 \\
28 & Unknown nobleman (second half 16th century) & 92 & 0.60 & 0.53 \\
33 & Charles Tocco $(\dagger 1710)$ & 131 & 0.08 & 0.05 \\
\hline
\end{tabular}


vita" exposure to mercury (Katz and Katz 1992; Hansen et al. 1983). The mercury hair concentrations obtained in the ten individuals with no $\mathrm{Hg}$ in the hair washing liquid are shown in Table 4: seven are positive, with mercury values between 411 and $47 \mathrm{ppm}$.

\section{Discussion and conclusions}

\section{Mercury therapies in the Renaissance}

According to all historical sources, syphilis suddenly appeared in Europe at the end of the 15th century (Arrizabalaga et al. 1997; Tognotti 2009). The origin of the disease, either from the New or from the Old World, remains one of the greatest issues of palaeopathology, and is still discussed by scholars (Baker and Armelagos 1988; Meyer et al. 2002; Rothschild 2005; Harper et al. 2011; Walker et al. 2015).

A wide variety of mercury preparations were used for anti-syphilitic therapy, in the form of salves, fumigations, and ointments for the treatment of ulcers and luetic swellings, mostly based on cinnabar (Tognotti 2006).

In a recipe of the so-called Neapolitan ointment of the year 1509 , we read that three ounces (ca $80 \mathrm{~g}$ ) of quicksilver were mixed with about 5 ounces of pork fat (ca $134 \mathrm{~g}$ ) and salt. With this compound, the patient had to be anointed from head to toe (Corradi 1884).

In his famous three-book poem titled "Syphilis seu morbus gallicus," Hyeronimus Fracastorius wrote that the doctors would isolate, purge, and bleed the patients, covering their skin with mercury ointments or forcing them to inhale the mercury fumes (Fracastoro 1548).

Fracastorius gives suggestions for the preparation of an excellent ointment: "quick-silver" (metallic mercury), pig fat, horse fat, piceous terebinth, male incense, lentisk oil, myrrh drops, and sulphur ("which does not know fire"). He poetically reported that only three ointment applications were sufficient for the patient to recover, but the Renaissance doctors well knew that the mercurial therapy was to be continued for years (Asfiya et al. 2018).

Fumigations were produced by the combustion of a mercury mineral, generally cinnabar, in a small chamber which consisted in a wooden barrel, where the syphilitic patient would be hermetically closed, with only his head emerging (Fig. 4) (Quétel 1990; Powell and Cook 2005; Tognotti 2006).

These mercury-based therapies led to a rapid resolution of skin lesions, apparently yielding very good results. The Renaissance doctors exploited mercurial therapy on the basis of the galenic "humoral theory," according to which the disease is caused by an imbalance between the four humours of the body (blood, phlegm, yellow bile, and black bile), and they were convinced that the benefits of the cure derived from the emission from the body of some corrupted humours, in the form of very abundant salivation and intestinal disturbances like diarrhoea (O'Shea 1990). On the contrary, as we currently know, all these were symptoms of severe mercury intoxication. Doctors therefore strongly abused of the drug, to the point of killing by intoxication the patients who had not already been killed by syphilis (Wear 2000; Tognotti 2006). Apart from syphilis, the use of mercury is also testified for other diseases with cutaneous manifestations, such as mammary cancer (Hajdu 2011) or pediculosis, as in the case of the treatment of lice in Ferdinand II of Aragon (Fornaciari et al. 2011). However, its use for the treatment of "the French Disease" was certainly more frequent, as ironically suggested by the proverbial expression «a night with Venus, the entire life with Mercury» (Asfiya et al. 2018).

Table $4 \mathrm{Hg}$ concentration in hair samples with negative washing liquid by flame emission spectrometry

\begin{tabular}{lllccl}
\hline NASD & Name and chronology & Hair Hg (ppm) & Dev. St. & C. V. \% & $\begin{array}{l}\text { Blood Hg (ppm) } \\
\text { (estimated according to a hair-to-blood } \\
\text { mercury concentration ratios 250-300:1) }\end{array}$ \\
\hline 19 & Joan IV of Aragon (1479-1518) & & 1.48 & 0.88 & $0.56-0.67$ \\
17 & Isabel of Aragon (1470-1524) & 167 & 11.16 & 4.35 & $1.37-1.64$ \\
$11-\mathrm{a}$ & Ferdinand Francis of Avalos (1490-1525) & 218 & 2.27 & 0.83 & $0.73-0.87$ \\
$11-\mathrm{b}$ & Victoria Colonna (1492-1547) & 0 & - & - & - \\
14 & Ferdinand Orsini (1485-1549) & 233 & 0.62 & 0.27 & $0.78-0.93$ \\
16 & Mary of Aragon (1503-1568) & 100 & 0.72 & 0.58 & $0.33-0.40$ \\
5 & Unknown young girl (second half 16th century) & 47 & 0.05 & 0.28 & $0.16-0.19$ \\
24 & Unknown baby (second half 16th century) & 0 & - & - & - \\
31 & Catherine of Moncada (1611-1659) & 127 & 0.59 & 0.46 & $0.42-0.51$ \\
26 & Unknown noblewoman (17th century) & 0 & - & - & - \\
\hline
\end{tabular}


Fig. 4 The cure of syphilis with mercury fumigations in an engraving by Jacques Lagnier $(1659-1663)$

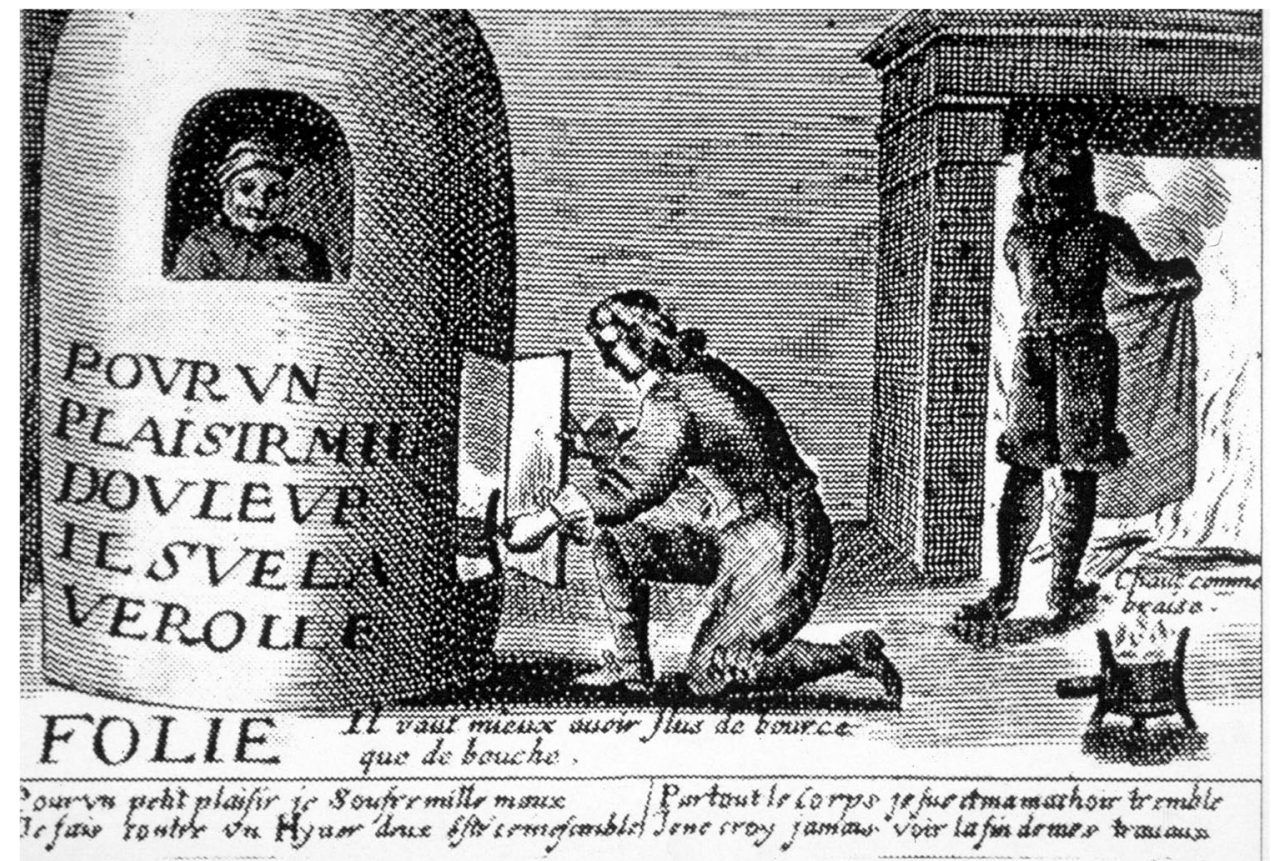

\section{Mercury cosmetics in Renaissance}

The collection of Renaissance recipes with mercury included the manuscript recipe book of Caterina Sforza (1463-1509), Countess of Forlì and mother of Giovanni de' Medici (Pasolini 1894), or the recipe book of Giovanventura Rosetti, printed in Venice in 1555. In these texts, the ladies of those times were the recipients of mercury-based cosmetics containing quicksilver, powder of quicksilver, and corrosive sublimates. Rosetti (1555) suggests cinnabar (mercury sulphide) as the compound of a potion aimed to remove bad breath, even if the author does not recommend its prolonged use because of the toxicity of the red mercury sulphide. Cinnabar was also commonly used as a rouge-type cosmetic or included among darkening substances called "browning" for cosmetics (Fornaciari et al. 2011). However, mercury-based cosmetics did not have to produce a level of intoxication comparable to exposure to mercury in anti-syphilitic therapy.

\section{Mercury for embalming in the Renaissance}

In the series of mummies of Saint Domenico Maggiore in Naples, two artificially embalmed individuals of the 16th century, an adult male (NASD 8) and an infant (NASD 2), showed macroscopic traces of mercury in the filling of their bodies. The metal was used in such high quantities that during the unwrapping operations and the autopsies, little drops of metallic mercury poured out of the body cavities of these two mummies. Mercury was visible by radiological examination in the form of little rounded formations of radio-opaque density (Marinozzi 2013; Marinozzi and Fornaciari 2005).

\section{Mercury in the hair of Neapolitan nobles}

It is important to discriminate between the absorption of mercury in life and post-mortal treatment with mercurial substances. The presence of $\mathrm{Hg}$ in the hair washing liquid of four individuals (Table 2) can be explained in various ways, related to a topical use of mercury. The very abundant concentration of $\mathrm{Hg}$ in the hair of the individual NASD 8 (3232 ppm) can be attributed to the embalming process with mercurial substances. Droplets of mercury were observed macroscopically on the hair and inside the cavities of the skull and of the body already at the time of the autopsy of this artificial mummy, and were highlighted as small radioopaque rounded formations at X-ray. The preservative use of mercury in preparing the corpse is attested in France starting from the late Medieval Age (Charlier et al. 2013). Direct evidence of the practice in Italy is documented in the Basilica of Saint Domenico Maggiore also in another individual (NASD 2), a baby of about 2-6 months artificially embalmed (Marinozzi and Fornaciari 2005; Marinozzi 2013).

The hair sample of individual NASD 20, Ferdinand II of Aragon, King of Naples (1467-1496), showed a high concentration of mercury ( $827 \mathrm{ppm})$, and presence of this element also in the washing liquid of the hair confirms its external application. Examination with a stereomicroscope and SEM of the hair revealed a lice infestation. The high value of mercury might have been caused by antipediculosis therapy, used as topical medicament. It is likely that 
an antiputrefactive mercurial balm was used immediately after his death. However, we can exclude a considerable use of mercury for inner embalming because the macroscopic and radiological examination of the body cavities showed no traces of mercury; furthermore, the toxicological analysis of the skin sample and of the materials found in the body filling revealed much lower values of $\mathrm{Hg}$ than in the hair (Fornaciari et al. 2011; Lanzirotti et al. 2014).

Individuals NASD 28 and NASD 33, respectively, the artificial mummies of an unknown nobleman of the second half of the 16th century and of Charles Tocco, Duke of Sicignano $(\dagger 1710)$, revealed the presence of exogenous mercury in the hair washing liquid. This was probably related to the topical use of a compound with mercury: it is not possible to determine whether the compound was applied during life to treat some kind of disease, or after death for the embalming process, as a sort of antiputrefactive balm for external use. For the ten individuals with no external application of mercury, the $\mathrm{Hg}$ hair concentrations (Table 4) undoubtedly reflect the real "in vita" values: the bodies of San Domenico Maggiore cannot have been diagenesis because the mummies are not buried in soil but they are preserved in wooden sarcophagi in a subaerial environment. No traces of mercury were detected in the hair of three individuals, and the contents of mercury were very high in the hair of seven, reaching true toxic levels in almost all cases (Table 4).

Indeed, $\mathrm{Hg}$ blood values $<0.005-0.02 \mathrm{ppm}$ are considered "normal levels," but first adverse effects, like increased tremors, can be associated with concentrations of mercury starting from $0.01 \mathrm{ppm}$ (ATSDR 1999), whereas more than $0.3 \mathrm{ppm}$ of mercury blood levels imply a severe form of intoxication (Ferrara 1989). Symptoms of chronic poisoning from mercury are salivation, inflammation and ulceration of the mouth and throat, erethism (a condition of nervousness, irritability, insomnia, memory loss, and delirium), tremor, fatigue, weight loss, gastrointestinal disturbances, and kidney problems (Hu 2008; Aufderheide 1998). These symptoms were well known already in the Renaissance, for instance by Paracelsus, who described them in his tract on syphilis edited in 1529 (On the French Disease Three Books Para) (Gantenbein 2017). In any case, the concentrations of mercury estimated in the nobles of the Neapolitan court were so high that they certainly produced signs of chronic mercury intoxication. The cases of individuals with chronic mercury intoxication are discussed below, starting from those with higher $\mathrm{Hg}$ values in the hair.

In the case of the Duchess Isabel of Aragon (NASD 17), who presents elevated levels of mercury in the hair (411 $\mathrm{ppm})$, the most likely hypothesis is intoxication from mercury to cure venereal syphilis. This intoxication produced mercury stomatitis, with a black patina over the gums and teeth. The black patina, analysed by EDS, showed very high levels of Hg. The anti-syphilitic mercurial therapy was probably responsible for the in vivo exposure to mercury (D'Errico et al. 1988). According to her biography, Isabel enjoyed an active sexual life, with different partners, and, from an anamnestic point of view, this supports the indirect diagnosis of venereal syphilis.

In the case of Ferdinand Orsini (NASD 14), as an alternative or in addition to a possible anti-syphilitic therapy, we cannot exclude that the high rate of mercury (233 ppm) found in the hair was caused by a mercurial therapy used to cure the cancer that eventually led him to death. As a matter of fact, the basal cell carcinoma appeared in the form of an impressive cutaneous eruption on the right orbit and on the root of the nose, lasting several years (Gaeta et al 2017); mercury-based compresses or anointing oils may have been applied on the Duke's face. Topical mercurial therapies for cancer are testified in the Renaissance. For instance, in 1575, the famous surgeon Ambroise Pare treated the breast cancer of Madame de Montigny, a lady-in-waiting to Catherine de' Medici (Queen Mother of France), placing a sheet of lead smeared with quicksilver (mercury) over the tumour (Hajdu 2011; De Moulin 1983). The Paracelsian physicians also promoted the use of mercury and of other metals for the treatment of cutaneous cancer, even internally (Fornaciari et al. 2019; Hajdu 2005).

The Marquise of Pescara Ferdinand Francis of Avalos (NASD 11a) showed high values of mercury (218 ppm). We have little nosographic information on the Marquis of Pescara, but syphilis was extremely widespread in the armies of the early 16th century and among the military captains, who typically had extramarital affairs not only with stable lovers but also with prostitutes (Tognotti 2009; 2014; Fornaciari et al. 2020). Ferdinand Francis of Avalos died in 1525, right in the middle of the syphilitic pandemic in Europe. He is very likely to have been affected by "the French disease," and the $\mathrm{Hg}$ value in his hair suggests a probable mercurial therapy for syphilis. Queen Joan IV (NASD 19), the Duchess Catherine of Moncada (NASD 31) and Mary of Aragon (NASD 16), presented lower values of mercury, respectively of 167,127 , and $100 \mathrm{ppm}$, possibly indicating a less drastic anti-luetic therapy. Queen Joan IV of Aragon, like her niece the Duchess Isabel of Aragon, had an active sexual life during her widowhood and the anamnestic data support the hypothesis that she contracted venereal syphilis. As regards Catherine of Moncada, the historical sources inform us that her husband Louis William of Moncada suffered from a venereal disease, most likely syphilis, in the year 1648-1649 (Pilo 2010). It is thus highly probable that she contracted the disease and that she followed a mercurial anti-luetic therapy. We also know that breast cancer led the lady to death, and so we cannot rule out that a mercury treatment for cancer accompanied the last years of Catherine's life (Pilo 2018). Finally, Mary of Aragon was affected by tertiary syphilis and by condyloma acuminatum, diagnosed 
by the palaeopathological study of her mummy; therefore, the mercury detected in the hair can certainly be attributed to an anti-syphilitic treatment (Fornaciari et al. 1989d, 2003).

The minimal positive value ( $47 \mathrm{ppm})$ is that of an anonymous young girl (NASD 5). According to the literature data, concentrations in hair higher than 5-16 ppm (Katz and Katz 1992), or higher than $36 \mathrm{ppm}$ (Nakagawa 1995), indicate a certain, strong exposure to the metal. Most recent literature reports mercury values in hair in subjects exposed in the occupational environment up to $6 \mathrm{ppm}$ too (Astolfi et al. 2020). Another study on human hair collected from different resident settlements exposed showed mercury concentrations ranged from 1.57 to $12.61 \mathrm{ppm}$, with a mean value of 4.29 \pm 3.25 ppm (Jia et al. 2018).

The lower concentration of mercury in this individual is likely to have depended on the mercurial treatment of a non-venereal, perhaps cutaneous, disease, or on cosmetics. Finally, no traces of mercury were found in two other female subjects (NASD 26 and NASD 11b) and in the very young baby (NASD 24) affected by a severe exanthematous disease (Fornaciari and Marchetti 1986; Patterson Ross et al. 2018).

Out of the fourteen individuals analysed, four presented mercury concentrations in the hair washing liquid which indicated external perimortem application, in one case clearly linked to embalming, and in the other three cases probably associated with topical therapeutic practices. Seven out of the other ten individuals had mercury values ranging from 411 to $47 \mathrm{ppm}$, which indicate prolonged exposure in life to the metal, most likely due to mercurial therapy.

In conclusion, this study is currently the first toxicological research aimed to detect the presence of mercury in the hair of such a large number of mummified bodies of the Italian Renaissance. The bodies belonged to well-known historical figures, and information on their habits and lifestyles have reached us from historical sources and from previous palaeopathological studies. Direct evidence of a strong exposure to mercury clearly emerges as a consequence of its indiscriminate use in 16th and 17th century therapies and, indirectly, of the extraordinary diffusion of venereal syphilis in the Italian upper classes during the "epidemic" phase of the disease.

\section{Availability of data and material and code availability}

The authors declare that all data and materials as well as software application or custom code support their published claims and comply with field standards.

Author contribution All authors had access to the data and played a role in writing this manuscript.
Funding Fondazione Arpa (https://fondazionearpa.it).

\section{Declarations}

Conflict of interest The authors declare no competing interests.

Open Access This article is licensed under a Creative Commons Attribution 4.0 International License, which permits use, sharing, adaptation, distribution and reproduction in any medium or format, as long as you give appropriate credit to the original author(s) and the source, provide a link to the Creative Commons licence, and indicate if changes were made. The images or other third party material in this article are included in the article's Creative Commons licence, unless indicated otherwise in a credit line to the material. If material is not included in the article's Creative Commons licence and your intended use is not permitted by statutory regulation or exceeds the permitted use, you will need to obtain permission directly from the copyright holder. To view a copy of this licence, visit http://creativecommons.org/licenses/by/4.0/.

\section{References}

Archi A (1968) Gli Aragona di Napoli. Cappelli Editore, Napoli

Arriaza B, Amarasiriwardena D, Cornejo L, Standen V, Byrne S, Bartkus B, Bandak B (2010) Exploring chronic arsenic poisoning in pre-Columbian Chilean mummies. J Archaeol Sci 37:1274-1278. https://doi.org/10.1016/j.jas.2009.12.030

Arrizabalaga J, Henderson J, French R, French RK (1997) The Great Pox: the French disease in Renaissance Europe. Yale University Press, New Haven (CT)

Asfiya A, Pinto M, Shenoy MM (2018) 'A night with Venus, a lifetime with Mercury': insight into the annals of syphilis. Arch Med Health Sci 6(2):290-292. https://doi.org/10.4103/amhs.amhs_ 131_18

Astolfi ML, Protano C, Marconi E, Massimi L, Piamonti D, Brunori M, Vitali M, Canepari S (2020) Biomonitoring of mercury in hair among a group of Eritreans (Africa). Int J Environ Res Public Health 17(6): 1911

ATSDR (1999) Toxicological profile for mercury. Agency for Toxic Substances and Disease Registry U.S. Department of Health and Humna Services. https://wwwn.cdc.gov/TSP/ToxProfiles/ToxPr ofiles.aspx ?id $=115 \&$ tid $=24$

Aufderheide AC (1998) The Cambridge encyclopaedia of human paleopathology. Cambridge University Press, Cambridge

Baker BJ, Armelagos GJ (1988) The origin and antiquity of syphilis. Paleopathological diagnosis and interpretation. Curr Anthropol 29:703-737. https://doi.org/10.1086/203691

Bartkus L, Amarasiriwardena D, Arriaza B, Bellis D, Yañez J (2011) Exploring lead exposure in ancient Chilean mummies using a single strand of hair by laser ablation-inductively coupled plasmamass spectrometry (LA-ICP-MS). Microchem J 98:267-274. https://doi.org/10.1016/j.microc.2011.02.008

Byrne S, Amarasiriwardena D, Bandak B, Bartkus L, Kane J, Jones J, Yañez J, Arriaza B, Cornejo L (2010) Were Chinchorros exposed to arsenic? Arsenic determination in Chinchorro mummies' hair by laser ablation inductively coupled plasma-mass spectrometry (LA-ICP-MS). Microchem J 94:28-35. https://doi.org/10.1016/j. microc.2009.08.006

Charlier P, Poupon J, Jeannel GF, Favier D, Popescu SM, Weil R, Moulherat C, Huynh, Charlier I, Dorion-Peyronnet C, Lazar AM, Hervé C, de la Grandmaison GL (2013) The embalmed heart of Richard the Lionheart (1199 A.D.): a biological and anthropological analysis. Sci Rep 3:1296 https://doi.org/10.1038/srep01296 
Charlier P, Huynh-Charlier I, Poupon J, Lancelot E, Campos PF, Favier D, Jeannel GF, Bonati MR, de la Grandmaison GL, Hervé C (2014) A glimpse into the early origins of medieval anatomy through the oldest conserved human dissection (Western Europe, 13(th) c. A.D.). Arch Med Sci 10:366-373. https://doi.org/10. 5114/aoms.2013.33331

Clarkson TW, Magos L, Myers GJ (2003) The toxicology of mercury-current exposures and clinical manifestations. N Engl J Med 349:1731-1737. https://doi.org/10.1056/NEJMra022471

Clarkson TW, Magos L, Myers GJ (2003) Human exposure to mercury: the three modern dilemmas. J Trace Elem Exp Med 16:321-343. https://doi.org/10.1002/jtra.10050

Chevallier P, Ricordel I, Meyer G (2006) Trace element determination in hair by synchrotron X-ray fluorescence analysis: application to the hair of Napoleon I. X-Ray Spectrom 35:125-130. https://doi. org/10.1002/xrs.878

Corradi A (1884) Nuovi documenti per la storia delle malattie veneree in Italia dalla fine del Quattrocento alla metà del Cinquecento. Ann Univ Med Chir 269:289-384

D’Arbitrio N (2001) San Domenico Maggiore "La Nova Sacristia": Le arche, gli apparati e gli abiti dei re aragonesi. Edizioni Savarese, Napoli

Debus AG (2002) The chemical philosophy: Paracelsian science and medicine in the sixteenth and seventeenth centuries. Dover Publications, New York

De Moulin D (1983) A short history of breast cancer. Springer, Netherlands, Dondrecht

D’Errico F, Villa G, Fornaciari G (1988) Dental esthetics of an Italian Renaissance noble-woman, Isabella d'Aragona. A case of chronic mercury intoxication. Ossa 13:233-54

Drew-Bear A (1994) Painted faces on the Renaissance stage: the moral significance of face-painting conventions. Bucknell University Press, Lewisburg (PA)

Egeland GM, Ponce R, Knecht R, Bloom NS, Fair J, Middaugh JP (1999) Trace metals in ancient hair from the Karluk Archaeological Site, Kodiak, Alaska. Int J Circumpolar Health 58:52-56

Egeland GM, Ponce R, Bloom NS, Knecht R, Loring S, Middaugh JP (2009) Hair methylmercury levels of mummies of the Aleutian Islands, Alaska. Environ Res 109:281-286. https://doi.org/10. 1016/j.envres.2008.11.004

Ferrara SD (1989) Il laboratorio di farmacologia e tossicologia clinica. Edizioni Medico Scientifiche, Torino

Fiorentino F (1911) Studi e ritratti della Rinascenza. Giuseppe Laterza \& Figli, Bari

Fornaciari A, Gaeta R, Chericoni S, Stefanelli F, Naccarato AG, Castagna M, Lencioni R, Giuffra V, Fornaciari G (2019) Cancer and therapy in the 16th century: the unique case of adenocarcinoma in Luigi Carafa, Prince of Stigliano (1511-1576). Lancet Oncol 20(12):1641-1642. https://doi.org/10.1016/S1470-2045(19)30680-1

Fornaciari A, Gaeta R, Minozzi S, Giuffra V (2020) Syphilis in Maria Salviati (1499-1543) wife of Giovanni de' Medici of the black bands. Emerg Infect Dis 26(6):1274-1282. https://doi.org/10. 3201/eid2606.180786

Fornaciari G, Marchetti A (1986) Intact smallpox virus particles in an Italian mummy of the XVI century: an immuno-electron microscope study. Paleopathol Newsl 56:7-12

Fornaciari G, Brogi G, Menconi A, Pollina L (1989a) Dental pathology of a wealthy class of Italian Renaissance: the mummies of the Abbey of S. Domenico Maggiorein Naples (XVI century). In : Capasso L (ed) Advances in paleopathology, J Paleopath Monogr Public 1, pp 57-58

Fornaciari G, Bruno J, Corcione N, Tornaboni D, Tognetti A (1989b) Blessure mortelle de pointe dans une momie de sexe masculin de la Basilique de S. Domenico Maggiore à Naples (XVIe siècle). In : Capasso L (ed) Advances in paleopathology, J Paleopath Monogr Public 1, pp 71-74.
Fornaciari G, Bruno J, Corcione N, Tornaboni D, Castagna M (1989c) Un cas de tumeur maligne primitive de la région nasoorbitaire dans une momie de la Basilique de S. Domenico Maggiore à Naples (XVIe siècle). In : Capasso L (ed) Advances in paleopathology, J Paleopath Monogr Public 1, pp 65-69.

Fornaciari G, Castagna M, Tognetti A, Tornaboni D, Bruno J (1989d) Syphilis in a Renaissance Italian mummy. Lancet 8663:614. https://doi.org/10.1016/s0140-6736(89)90729-0

Fornaciari G (1998) Italian mummies. In: Cockburn A, Cockburn E, Reyman TA (eds) Mummies, disease \& ancient cultures. Cambridge University Press, Cambridge, pp 271-80

Fornaciari G, Zavaglia K, Giusti L, Vultaggio C, Ciranni R (2003) Human papillomavirus (HPV) in a 16th century Italian mummy. Lancet 362(9390):1160. https://doi.org/10.1016/S0140-6736(03) 14487-X

Fornaciari G (2006) Le mummie Aragonesi in San Domenico Maggiore di Napoli. Med Secoli 18:843-886

Fornaciari G, Giuffra V, Marinozzi S, PicchiMalayka S, Masetti M (2009) Royal" pediculosis in Renaissance Italy: lice in the mummy of the King of Naples Ferdinand II of Aragon (1467-1496). Instituto Oswaldo Cruz, Rio de Janeiro. Memorias 104:671-672. https://doi.org/10.1590/S0074-02762009000400026

Fornaciari G, Marinozzi S, Cazzaniga V, Giuffrà V, Picchi MS, Giusiani M, Masetti M (2011) The use of mercury against pediculosis in the Renaissance: the case of Ferdinand II of Aragon, King of Naples, 1467-96. Med Hist 55:109-115. https://doi.org/10.1017/ s0025727300006074

Fornaciari G (2018) Histology of ancient soft tissue tumors: a review. Intern J Paleopathol 21:64-76. https://doi.org/10.1016/j.ijpp.2017. 02.007

Fracastoro H (1548) De contagione et contagiosis morbis et eorum curatorie, libri III. WC. Putnam, New York, 1930

Fresnais M, Richardin P, Gimat A, Sepúlveda M, Leize-Wagner E, Charrié A (2015) Recent advances in the characterization of hair of mummies from the Chilean Andean coast. Forensic Sci Int 249:25-34. https://doi.org/10.1016/j.forsciint.2015.01.005

Gaeta R, Ventura L, Fornaciari G (2017) The cutaneous cancer of Ferdinando Orsini, 5th Duke of Gravina. Jama Dermatol 153(7):643. https://doi.org/10.1001/jamadermatol.2017.1847

Gantenbein UL (2017) Poison and its dose: paracelsus on toxicology. In: Wexler P (ed) Toxicology in the Middle Ages and Renaissance. Academic Press, London, pp 1-10. https://doi.org/10.1016/ B978-0-12-809554-6.00001-9

Giuffra V, Marinozzi S, Vultaggio C, Fornaciari G (2008) A medical bandage in an Italian Renaissance mummy (Naples, XVI century). Med Secol 20(1):169-181

Hajdu SI (2005) 2000 years of chemotherapy of tumors. Cancer. 103(6):1097-102. https://doi.org/10.1002/cncr.20908

Hajdu SI (2011) A note from history: landmarks in history of cancer, part 2. Cancer 117:2811-2820. https://doi.org/10.1002/cncr. 25825

Hansen JC, Wulf HC, Kromann N, Albore K (1983) Human exposure to heavy metals in East Greenland. I Mercury. Sci Total Environ 26:233-43. https://doi.org/10.1016/00489697(83)90141-9

Harper KN, Zuckerman MK, Harper ML, Kingston JD, Armelagos GJ (2011) The origin and antiquity of syphilis revisited: an appraisal of Old World pre-Columbian evidence for treponemal infection. Yearb Phys Anthropol 54:54-99. https://doi.org/10.1002/ajpa. 21613

Hu H (2008) Heavy metal poisoning. In Harrison's principles of internal medicine,17th edn. McGraw-Hill Professional, New York, pp e277-e279. https://doi.org/10.1111/j.1445-5994.2008. 01837.x 
Jia Q, Zhu X, Hao Y, Yang Z, Wang Q, Fu H, Yu H (2018) Mercury in soil, vegetable and human hair in a typical mining area in China: implication for human exposure. J Environ Sci (China) 68:73-82. https://doi.org/10.1016/j.jes.2017.05.018

Kakoulli I, Prikhodko SV, Fischer C, Cilluffo M, Uribe M, Bechtel HA, Fakra SC, Marcus MA (2014) Distribution and chemical speciation of arsenic in ancient human hair using synchrotron radiation. Anal Chem 86:521-526. https://doi.org/10.1021/ac402 4439

Katz SA, Katz RB (1992) Use of hair analysis for evaluating mercury intoxication of the human body: a review. J Appl Toxicol 12:79-84. https://doi.org/10.1002/jat.2550120203

Kepa M, Kozłowski T, Szostek K, Drozd A, Walas S, Mrowiec H, Stepańczak B, Głab H, Grupa M (2012) Analysis of mercury levels in historical bone material from syphilitic subjects-pilot studies (short report). Anthropol Anz 69:367-77. https://doi.org/ 10.1127/0003-5548/2012/0163

Kim GY, Seo JW, Kim BG, Kim YM, Kim RB, Kim JM, Kim CJ, Hong YS (2013) Correlation between hair mercury concentration blood total mercury in several area residents. J Environ Health Sci 39:117-129. https://doi.org/10.5668/JEHS.2013. 39.2.117

Lanzirotti A, Bianucci R, LeGeros R, Bromage TG, Giuffra V, Ferroglio E, Fornaciari G, Appenzeller O (2014) Assessing heavy metal exposure in Renaissance Europe using synchrotron microbeam techniques. J Archaeol Sci 52:204-217. https://doi.org/10.1016/j. jas.2014.08.019

Le Roy GA (1919) Sur un mode d'embaumement mercurial à l'époque médiévale. Note présentée à l'Académie des Sciences de Paris, à la séance du 16 décembre 1918. Gauthier-Villard, Paris

Marinozzi S (2013) Bodies, mummies and texts for an history of embalming in Italy. Med Secoli 25:167-204

Marinozzi S, Fornaciari G (2005) Le mummie e l'arte medica nell'evo moderno. Medicina nei Secoli, supplemento 1. Università 'La Sapienza', Roma

McDowell MA, Dillon CF, Osterloh J, Bolger PM, Pellizzari E, Fernando R, Montes de Oca R, Schober SE, Sinks T, Jones RL, Mahaffey KR (2004) Hair mercury levels in U.S. children and women of childbearing age: reference range data from NHANES 1999-2000. Environ Health Perspect 112:1165-1171. https://doi. org/10.1289/ehp.7046

Meyer C, Jung C, Kohl T, Poenicke A, Poppe A, Alt W (2002) Syphilis 2001-a paleopathological reappraisal. Homo 53:39-58. https:// doi.org/10.1078/0018-442X-00037

Nakagawa R (1995) Concentration of mercury in hair of diseased people in Japan. Chemosphere 30:135-140. https://doi.org/10.1016/ 0045-6535(94)00383-6

Nuttal KL (2006) Interpreting hair mercury levels in individual patients. Am Clin Lab Sci 36:248-261 (https://doi.org/0091-7370/ 06/0300-0248)

O'Shea JG (1990) 'Two minutes with Venus, two years with Mercury'-mercury as an antisyphilitic chemotherapeutic agent. J R Soc Med 83:392-395

Pasolini P (1894) Gli Experimenti de la ex.ma Sr Caterina da furlj Matre de lo inlluxmo Signor Giouanni de Medici. Tipografia d'Ignazio Galeati e figlio, Imola

Patrizi G (1982) Colonna, Vittoria. Dizionario biografico degli italiani 27, Istituto dell'Enciclopedia Italiana, Roma, pp 448-457

Patterson Ross Z, Klunk, J, Fornaciari G, Giuffra V, Duchêne S, Duggan AT, Poinar D, Douglas MW, Eden JS, Holmes EC, Poinar HN (2018) The paradox of HBV evolution as revealed from a 16th century mummy PLoS Pathog 14 (1):e1006750 Published 2018 Jan 4. https://doi.org/10.1371/journal.ppat.1006750.

Pepe L (1900) Storia della successione degli Sforzeschi negli Stati di Puglia e Calabria. Vecchi, Bari
Pilo R (2010) Scienza e politica negli scritti del medico di corte Gavino Farina. Estudis. Rev Hist Mod 36:175-187

Pilo R (2018) Estudio para el retrato de una dama: Catalina Moncada de Castro desde el monasterio de Pedralbes hasta la corte de Madrid. Estudis. Rev Hist Mod 44:159-172

Powell ML, Cook DC (2005) The myth of syphilis: the natural history of treponematosis in North America. University Press of Florida, Florida, Gainesville

Quétel C (1990) The history of syphilis. John Hopkins University Press, Baltimore (MD)

Rasmussen KL, Boldsen JL, Kristensen HK, Skytte L, Hansen KL, Mølholm L, Grootes PM, Nadeau MJ, Flöche Eriksen KM (2008) Mercury levels in Danish Medieval human bones. J Archaeol Sci 35:2295-2306. https://doi.org/10.1016/j.jas.2008.03.003

Reiter C (1994) Das Skelett des Paracelsus aus gerichtsmedizinischer Sicht. In: Dopsch H, Kramml PF (ed) Paracelsus und Salzburg. Mitteilungen der Ges. für Salzburger Landeskunde 14, Ergänzungsband, Im Selbstverlag der gesellschaft, Salzburg, pp $97-116$

Rosetti G (1555) Notandissimi secreti de l'arte profumatoria, Venezia. [Reprinted by Neri Pozza Editore, Vicenza 1973]

Rothschild MB (2005) History of syphilis. Clin Infect Dis 40:1454-63. https://doi.org/10.1086/429626

Scandone A (1930) Le tristi reyne di Napoli. Cooperativa Tipografica Sanitaria, Napoli

Shamà D (2013) I di Tocco, Sovrani dell'Epiro e di Leucade. Studio storico-genealogico. Notiziario ANRV 5:45-118

Taylor FL (1973) The art of war in Italy, 1494-1529. Greenwood Press, Westport

Tilles G, Wallach D (1996) Histoire du traitement de la syphilis par le mercure: 5 siècles d'incertitudes et de toxicité. Rev Hist Pharm 312:347-51

Tognotti E (2006) L'altra faccia di Venere. La Sifilide dalla prima età moderna all'avvento dell'Aids (XV-XX sec.). Franco Angeli, Milano

Tognotti E (2009) The rise and the fall of syphilis in Renaissance Europe. Eur J Med Humanit 30:99-113. https://doi.org/10.1007/ s10912-009-9079-3

Tognotti E (2014) Prevention strategies and changes in sexual mores in response to the outbreak of syphilis in Europe in the Early Modern Age. J Anc Dis Prev Rem 2:113. https://doi.org/10.4172/ 2329-8731.1000113

Toribara TY (2001) Analysis of single hair by XRF discloses mercury intake. Hum Exp Toxicol 20:185-188. https://doi.org/10.1191/ 096032701678766813

Toscano TR (1998) Vittoria Colonna. Sonetti in morte di Francesco Ferrante d'Avalos Marchese di Pescara. Editoriale Giorgio Mondadori, Milano

Tucker F (2007) Kill or cure? The osteological evidence of the mercury treatment of syphilis in 17 th to 19 th century London. Lond Archaeol 11:220-224. https://doi.org/10.5284/1071108

Epa US (2001) Water quality criterion for the protection of human health: methylmercury. US EPA, Washington DC

Volpicella S (1847) Principali edifici della città di Napoli. Storia dei Monumenti del Reame delle Due Sicilie. Stamperia e Cartiere del Fibreno, Napoli

Walker D, Powers N, Connell B, Redfern R (2015) Evidence of skeletal treponematosis from the Medieval burial ground of St. Mary Spital, London, and implications for the origins of the disease in Europe. Am J Phys Anthropol 156:90-101. https://doi.org/10.1002/ajpa. 22630

Wear A (2000) Medicine in Early Modern Europe, 1500-1700. In: Conrad L, Nutton V, Porter R, Wear A (eds) The Western medical tradition, $800 \mathrm{BC}$ to AD 1800. Cambridge University Press, Cambridge, pp 215-362 
Wilson AS (2005) Hair as a bioresource in archaeological study. In: Tobin DJ (ed) Hair in toxicology: an important biomonitor. Royal Society of Chemistry, Cambridge (MA), pp 321-345

WHO (1976) Environmental health criteria 1: mercury. WHO, Geneva Yamada M, Tohno S, Tohno Y, Minami T, Ichii M, Okazaki Y (1995) Accumulation of mercury in excavated bones of two natives in Japan. Sci Total Environ 162(2-3):253-256. https://doi.org/10. 1016/0048-9697(95)04435-4
Ye BJ, Kim BG, Jeon MJ, Kim SY, Kim HC, Jang TW, Chae HJ, Choi WJ, Ha MN, Hong YS (2016) Evaluation of mercury exposure level, clinical diagnosis and treatment for mercury intoxication. Ann Occup Environ Med 28:5. https://doi.org/10.1186/ s40557-015-0086-8

Publisher's Note Springer Nature remains neutral with regard to jurisdictional claims in published maps and institutional affiliations. 